\title{
Zinc availability in relation to selected soil properties in a crude oil polluted eutric tropofluvent
}

\author{
*M. C. Chukwuma; E. T. Eshett; E. U. Onweremadu; M. A. Okon \\ Soil Science and Technology Department, Federal University of Technology, P.M.B. 1526, \\ Owerri, Imo State, Nigeria \\ Received 2 July 2009; $\quad$ revised 1 February 2010; accepted 25 February 2010; avaiable online 1 March 2010
}

\begin{abstract}
The study investigated zinc availability in relation to selected soil properties in a crude-oil-polluted Eutric Tropofluvent in Egbema, Southeastern Nigeria. For this purpose, three treatments have been applied: unpolluted soil, polluted without vegetation and polluted with vegetation with five replicates arranged in a randomized complete block design. Guided by transect sampling technique, soil sampling was carried out in June 2008. Soil samples were collected from the three different land units using soil auger at a depth of 0-20 cm. Standard laboratory procedures were adopted in analysing the soils. Soil generated data were subjected to analysis of variance and correlation analysis. Results showed highly significant variation $(\mathrm{p}=0.01)$ in bulk density, porosity, silt: clay ratio, $\mathrm{pH}$, effective cation exchange capacity, percent base saturation, total nitrogen, organic matter, available phosphorus, calcium: magnesium ratio and zinc. It was found that zinc was higher in crude oil polluted soils than in non-polluted soil and it was below critical limits. Zinc availability in relation to selected soil properties in the crude oil polluted soils indicated that clay and organic matter did not affect zinc availability, while $\mathrm{pH}$ and effective cation exchange capacity did. A study on zinc dynamics in crude-oil-polluted soils will certainly provide further information on the management of crude-oil-polluted soils since it is one of the key micronutrient for crop productivity.
\end{abstract}

Keywords: Eutric tropofluvent; Soil properties; Spillage; Tropical soils; Zinc availability

\section{INTRODUCTION}

Soil is the aggregate of decaying organic matter (OM); living organisms and weathered mineral materials (Bellamy, 2007). Soils suffer from pollution (Onweremadu and Duruigbo, 2007) such as crude oil spillage. Crude oil which is abundantly located in the Niger-Delta region of Nigeria is spilled on soils due to several factors such as pipeline destruction (Nwilo and Badejo, 2001). Crude oil spillage on soils causes lots of adverse effects which hinder soil productivity (Udo and Fayemi, 1975; Rowell, 1977; Okpokwasili and Odokuna, 1990; Ladousse and Tramier, 1991).

In addition, the availability or otherwise of heavy metals and micronutrients such as zinc ( $\mathrm{Zn}$ ) is equally affected. Onweremadu and Duruigbo (2007) reported significant levels of heavy metals in soils that were contaminated with automobile waste oil. Zinc though a heavy metal is also micronutrient (Alvarez-Benedi and Munoz-Carpena, 2005). As a micronutrient, it has been indicated to be beneficial to both plants and

*Corresponding Author Email: chukwumamike@yahoo.co.uk Tel./Fax: +234 7035058211 animals (Alloway, 1995). It has however been observed that if $\mathrm{Zn}$ exceeds certain limits in soils it becomes toxic to biota (Alvarez-Benedi and Munoz-Carpena, 2005; Ogundiran and Afolabi, 2008 ). In the Netherlands, the critical limits of Zn in soils has been defined at $720 \mathrm{mg} /$ kg (NMHPPE, 1991).

A number of edaphic factors, including $\mathrm{pH}$, organic matter, effective cation exchange capacity and clay have been indicated to affect Zn availability in soils (Alloway, 1995; Okafor and Opuene, 2007; Nabulo et al., 2008). Zinc tends to be less available in soils with high $\mathrm{pH}$. In a study conducted on the effect of $\mathrm{pH}$ on the adsorption of zinc (Shuman, 1975), it was revealed that low $\mathrm{pH}$ reduced zinc adsorption more for the sandy soils than for those high in colloidal-size materials. Also, Shuman (1975) and Lorenz et al. (2000) separately observed that soils high in clay or organic matter had higher adsorptive capacities and higher bonding energies for zinc than sandy soils low in organic matter. Furthermore, zinc can interrupt the activities in soils, as it negatively influences the activity of microorganisms and earthworms (Suthar 
and Sing, 2008). This process affects the breakdown of organic matter. Smolders et al. (2004) reported the negative effect of zinc toxicity on soil microbial processes, as it hinders the activities of microorganisms. In view of these observed effects of selected soil physicochemical properties on zinc availability, a study on zinc availability in crude-oil polluted soils would help in providing valuable information in reclaiming such soils. Therefore, this investigation aimed at studying $\mathrm{Zn}$ availability in relation to selected soil properties in a crude oil polluted Eutric Tropofluvent, in Egbema, Imo State, Nigeria.

\section{MATERIALS AND METHODS}

\section{Study area}

The study was located at Ugwugba, Obiagbu in Ohaji-Egbema area of Imo State, southeastern Nigeria where crude oil spillage occurred for about two months. Egbema is situated at the northern apex area of the lower Niger Delta, between latitudes $5^{\circ} 21^{\prime}$ to $5^{\circ} 41^{\prime} \mathrm{N}$ and longitudes $6^{\circ} 37^{\prime}$ to $6^{\circ} 49^{\prime}$ E. Geomorphologically, Egbema is located at the flood plain of recent illuvial formation. The geology of the studied region is characterized by quarternary, alluvium, meander belt, wooded back swamps as well as fresh water swamps and Sombreiro-Warri Deltaic Plains with large deposit of petroleum and natural gas and oil deep-test wells (Orajaka, 1975). The annual mean temperature is between 26.5 and $27.5^{\circ} \mathrm{C}$, mean annual rainfall greater than $2500 \mathrm{~mm}$, mean daily relative humidity of 64 to 75 \%, evaporation of above $1450 \mathrm{~mm} / \mathrm{y}$. Major soils of the area have been classified as Eutric Tropofluvent (FDALR, 1985). Vegetation of the study site comprised some disturbed secondary forest, riparian forest and raffia, oil palm/food crop, mosaic commercial plantation, long cycle fallow areas and open field cultivation. Apart from crude oil exploration and exploitation, arable crop production is a major socio-economic activity of the area.

\section{Experimental design}

Three different land units: Unpolluted area $(0.5 \mathrm{~km}$ away from spillage site), polluted without vegetation and polluted area with vegetation served as treatments. Five samples in a transect intervals of $5 \mathrm{~m}$ (A, B C, D and $E$ ) per land unit were used as replicates which was arranged in a randomised complete block design.

\section{Soil sampling}

At the study site and guided by transect sampling technique, soil sampling was carried out in June 2008, about two months after the spillage occurred. Soil samples were collected at the plough layer $(0-20 \mathrm{~cm})$ at intervals of $5 \mathrm{~m}$ in each land unit i.e. polluted without vegetation, polluted with vegetation and unpolluted area . Five samples were collected from each sampling point making it a total of fifteen samples. Collected samples were thereafter air-dried, gently crushed and made to pass through two mm mesh sieve preparatory to laboratory analysis.

\section{Laboratory analysis}

Laboratory analyses were conducted for particle size distribution by hydrometer method (Gee and Or, 2002), bulk density by core method (Grossman and Reinsch, 2002), moisture content by gravimetric method (Obi, 1990), soil pH using pH meter (Hendershot et al., 1993), total carbon by wet digestion (Nelson and Sommers, 1982), available phosphorus according to the procedure of Olson and Sommers (1990), exchangeable bases by ammonium acetate leaching and exchangeable acidity by titration (McLean, 1982), total nitrogen by microkjeldahl digestion technique (Bremner, 1996). Base saturation was obtained by calculations (Exchangeable bases/Effective cation exchange capacity x 100).

\section{Determination of $\mathrm{Zn}$ in soils}

Zinc was determined in accordance with the procedure of Leschber et al. (1985). One gram dry soil finely ground, was moistened with distilled water and heated in a $100 \mathrm{~cm}^{3}$ Teflon beaker with $10 \mathrm{~cm}^{3}$ concentration $\mathrm{HNO}_{3}$ and evaporated to small volume. Then, $5 \mathrm{~cm}^{3}$ concentration $\mathrm{HNO}_{3}, 5 \mathrm{~cm}^{3} 70 \% \mathrm{HClO}_{4}$ and $10 \mathrm{~cm}^{3}$ concentration HF were added and the whole heated to perchlorate fumes. After $30 \mathrm{~min}$ fuming, 10 $\mathrm{cm}^{3}$ of $\mathrm{HCl}(1 / 1, \mathrm{v} / \mathrm{v})$ was added and the mixture boiled for $10 \mathrm{~min}$ and then cooled and diluted to $100 \mathrm{~cm}^{3}$ with distilled water. Zinc concentrations in the supernatant was determined using atomic adsorption spectrophotometer (S Series).

\section{Data analysis}

Generated soil data were subjected to analysis of variance (ANOVA) and means were separated using least significance difference (LSD) at $5 \%$ probability level. Zinc was correlated and regressed against selected soil properties and their simple coefficient of determinants were obtained. These were carried out 
with the aid of GenStat statistical software $8^{\text {th. }}$ Edition (Buysse et al., 2005).

\section{RESULTS AND DISCUSSION}

Soil physical properties

Selected physical properties of the studied soils are shown in Table 1. Sand, silt and clay values for the unpolluted soil was 899,83 and $21 \mathrm{~g} / \mathrm{kg}$, respectively, while for polluted without vegetation and polluted with vegetation it was 857, 113, 30 and 927, 51, $22 \mathrm{~g} / \mathrm{kg}$, respectively. Silt:clay ratio (SCR) was 4.0, 3.8 and 2.8 for unpolluted, polluted without vegetation and polluted with vegetation, respectively. It was obvious that the soils were characteristically sandy (Onweremadu, 2007). This was further evidenced by the textural class of the soils which was sandy, loamy and sandy for unpolluted, polluted without vegetation and polluted with vegetation, respectively. Soil bulk density ranged between 1.25 (unpolluted) and $1.36 \mathrm{~g} / \mathrm{cm}$ (polluted without vegetation). Sands and loam usually show bulk density variations of between 1.2 and $1.8 \mathrm{~g} / \mathrm{cm}$ (Unger and Kasper, 1994). On total porosity, the usual range for soils is from 30-70 \% (Landon, 1991). The total porosity for the soils were 52.1 (unpolluted), 48.7 (polluted without vegetation) and $49.8 \%$ (polluted with vegetation). Soil moisture values was 139, 210 and $167 \mathrm{~g} / \mathrm{kg}$ for unpolluted, polluted without vegetation and polluted with vegetation, respectively, indicating more moisture in polluted soils.

\section{Soil chemical properties}

Results of selected soil chemical properties of studied soils are presented in Table 2. Soil $\mathrm{pH}_{\text {water }}$ for unpolluted (6.48) was lower than that of polluted without vegetation (6.88) and that of polluted with vegetation (6.75). These results are consistent with that of Amadi et al. (1993), but varied from that of Isirimah et al. (1989). Soil effective cation exchange capacity for unpolluted was $9.50 \mathrm{mg} / \mathrm{kg}$, which was lower than that of polluted without vegetation $(25.39 \mathrm{mg} / \mathrm{kg})$ and polluted with vegetation $(14.31 \mathrm{mg} / \mathrm{kg})$. Soil available phosphorus (P) was least in polluted with vegetation $(1.25 \mathrm{mg} / \mathrm{kg})$ and the highest in unpolluted $(6.15 \mathrm{mg} /$ $\mathrm{kg})$ followed by polluted without vegetation $(3.2 \mathrm{mg} /$ $\mathrm{kg}$ ). This trend agrees with the findings of Amadi and Bari (1992). Total nitrogen (TN) and organic matter were least in unpolluted ( 0.13 and $189.6 \mathrm{mg} / \mathrm{kg}$, respectively) and highest in polluted without vegetation ( 0.17 and $320.6 \mathrm{mg} / \mathrm{kg}$, respectively). Calcium:Magnessium ratio was highest in unpolluted (4.52) and least in polluted without vegetation (0.18). Carbon:nitrogen ratio was 8.46 for unpolluted, 10.9 for polluted without vegetation and 10.5 for polluted with vegetation. This is in line with the results of Amadi and Bari (1992) who reported higher values of carbon:nitrogen ratio in crude-oilpolluted soils.

Fig. 1a shows Zn concentrations in studied soils with distance away from pollution site, while Fig. $1 \mathrm{~b}$ shows mean values of $\mathrm{Zn}$ at each land unit. Zinc had a mean value of $9.828 \mathrm{mg} / \mathrm{kgin}$ unpolluted, $15.684 \mathrm{mg} / \mathrm{kg}$

Table 1: Some physical properties of studied soils

\begin{tabular}{|c|c|c|c|c|c|c|c|c|}
\hline Sample & Sand & Silt & Clay & SCR & TC & $\ell \mathrm{b}$ & $\mathrm{F}$ & $\mathrm{MC}$ \\
\hline Unit & (g/kg) & & & - & & $(\mathrm{g} / \mathrm{cm})$ & (\%) & $(\mathrm{g} / \mathrm{kg})$ \\
\hline UP & 899 & 83 & 21 & 4.0 & S & 1.25 & 52.1 & 139 \\
\hline PwoV & 857 & 113 & 30 & 3.8 & $\mathrm{~L}$ & 1.36 & 48.7 & 210 \\
\hline
\end{tabular}

$\ell \mathrm{b}=$ Bulk density; $\mathrm{F}=$ Porosity; SCR= Silt:clay ratio $\mathrm{MC}=$ Moisture content; UP=Unpolluted soil; PwoV= Polluted without vegetation; PwV= Polluted with vegetation.

Table 2: Some chemical properties of studies soils

\begin{tabular}{|c|c|c|c|c|c|c|c|c|c|c|c|c|}
\hline Sample & $\mathrm{pH}$ & $\mathrm{Na}^{+}$ & $\mathrm{K}^{+}$ & $\mathrm{Mg}^{2+}$ & $\mathrm{Ca}^{2+}$ & ECEC & Av. P & $\mathrm{TN}$ & OM & BS & $\mathrm{C}: \mathrm{N}$ & C:M \\
\hline Unit & & & & & $(\mathrm{mg} / \mathrm{k}$ & & & & & (\%) & \multicolumn{2}{|c|}{ Ratio } \\
\hline UP & 6.48 & 0.59 & 0.92 & 1.40 & 6.10 & 9.50 & 6.15 & 0.13 & 189.6 & 94.8 & 8.46 & 4.52 \\
\hline PwoV & 6.88 & 0.81 & 1.17 & 19.52 & 3.53 & 25.39 & 3.20 & 0.17 & 320.7 & 98.5 & 10.9 & 0.18 \\
\hline $\mathrm{PwV}$ & 6.75 & 0.62 & 1.20 & 9.62 & 2.42 & 14.31 & 1.25 & 0.15 & 272.4 & 96.9 & 10.5 & 0.25 \\
\hline
\end{tabular}

ECEC= Effective cation exchange capacity; \% BS= Percent base saturation; TN= Total nitrogen; OM= Organic matter; Av.P= Available phosphorus: C:NR= Carbon:nitrogen ratio; C:MR= Calcium:magnessium ratio; UP= Unpolluted soil; PwoV= Polluted without vegetation; PwV= Polluted with vegetation. 
(polluted without vegetation) and $21.828 \mathrm{mg} / \mathrm{kg}$ (polluted with vegetation). This indicated higher values in polluted soils. Figs. 2 a-d, 3 a-d and 4 a-d show linear relationship between $\mathrm{Zn}$ and selected soil properties. Among the treatment means, $\mathrm{Zn}$ had a high significant difference at $\mathrm{p}=0.01$ (Table 5 ).

Table 4 shows variability in some physicochemical properties of studied soils. Bulk density, porosity, silt:clay ratio, $\mathrm{pH}$, effective cation exchange capacity, percent base saturation, total $\mathrm{N}$, organic matter, available $\mathrm{P}$ and calcium:magnesium ratio showed high significant difference at $\mathrm{p}=0.01$. In contrast, clay indicated significant difference at $\mathrm{p}=0.05$ among treatment means, while carbon:nitrogen did not show any significance difference at $\mathrm{p}=0.05$. Table 3 shows correlation matrix among physicochemical properties of the three sampling positions.

\section{Physical properties}

Aggressive weather conditions of the area may have contributed to the nature of the soils' texture (Jungeruis and Levellt, 1964). High precipitation in the area

Table 3: Correlation matrix among physiochemical properties on the three sampling positions

\begin{tabular}{|c|c|c|c|c|c|c|c|c|c|c|c|}
\hline & & $\begin{array}{c}\text { Clay } \\
\text { (g/kg) }\end{array}$ & $\begin{array}{l}\ell \mathrm{b} \\
(\mathrm{g} / \mathrm{cm})\end{array}$ & $\begin{array}{l}\mathrm{F} \\
(\%)\end{array}$ & $\begin{array}{c}\text { SCR } \\
- \\
\end{array}$ & $\begin{array}{l}\mathrm{pH} \\
- \\
\end{array}$ & $\begin{array}{l}\text { ECEC } \\
\text { (mg/kg) }\end{array}$ & $\begin{array}{l}\text { BS } \\
\text { (\%) }\end{array}$ & $\begin{array}{l}\mathrm{TN} \\
(\mathrm{mg} / \mathrm{kg})\end{array}$ & $\begin{array}{l}\mathrm{OM} \\
(\mathrm{g} / \mathrm{kg})\end{array}$ & $\begin{array}{l}\begin{array}{l}\text { Av.P } \\
\text { (mg/kg) }\end{array} \\
\end{array}$ \\
\hline \multirow[t]{3}{*}{ Clay } & UP & 1.0 & & & & & & & & & \\
\hline & PwoV & 1.0 & & & & & & & & & \\
\hline & $\mathrm{PwV}$ & 1.0 & & & & & & & & & \\
\hline \multirow[t]{3}{*}{$\ell b$} & UP & $0.09^{\mathrm{NS}}$ & 1.00 & & & & & & & & \\
\hline & PwoV & $0.016^{\mathrm{NS}}$ & 1.00 & & & & & & & & \\
\hline & $\mathrm{PwV}$ & $0.61^{\mathrm{NS}}$ & 1.00 & & & & & & & & \\
\hline \multirow[t]{3}{*}{ F } & UP & $0.09^{\mathrm{NS}}$ & 1.00 & 1.00 & & & & & & & \\
\hline & PwoV & $0.017^{\mathrm{NS}}$ & 1.00 & 1.00 & & & & & & & \\
\hline & $\mathrm{PwV}$ & $0.64^{\mathrm{NS}}$ & 1.00 & 1.00 & & & & & & & \\
\hline \multirow[t]{3}{*}{ SCR } & UP & 0.98 & $0.09^{\mathrm{NS}}$ & $0.091^{\mathrm{NS}}$ & 1.00 & & & & & & \\
\hline & PwoV & 0.96 & $0.074^{\mathrm{NS}}$ & $0.074^{\mathrm{NS}}$ & 1.00 & & & & & & \\
\hline & $\mathrm{PwV}$ & 0.67 & $0.78^{\mathrm{NS}}$ & 0.80 & 1.00 & & & & & & \\
\hline \multirow[t]{3}{*}{ pH } & UP & $0.01^{\mathrm{NS}}$ & $0.065^{\mathrm{NS}}$ & $0.064^{\mathrm{NS}}$ & $0.00^{\mathrm{NS}}$ & 1.00 & & & & & \\
\hline & PwoV & $0.234^{\mathrm{NS}}$ & $0.01^{\mathrm{NS}}$ & $0.01^{\mathrm{NS}}$ & $0.256^{\mathrm{NS}}$ & 1.00 & & & & & \\
\hline & $\mathrm{PwV}$ & $0.87^{\mathrm{NS}}$ & 0.88 & 0.90 & 0.861 & 1.00 & & & & & \\
\hline \multirow[t]{3}{*}{ ECEC } & UP & $0.042^{\mathrm{NS}}$ & $0.023^{\mathrm{NS}}$ & $0.021^{\mathrm{NS}}$ & $0.005^{\mathrm{NS}}$ & $0.069^{\mathrm{NS}}$ & 1.00 & & & & \\
\hline & PwoV & $0.00^{\mathrm{NS}}$ & $0.29^{\mathrm{NS}}$ & $0.29^{\mathrm{NS}}$ & $0.00^{\mathrm{NS}}$ & $0.24^{\mathrm{NS}}$ & 1.00 & & & & \\
\hline & $\mathrm{PwV}$ & $0.37^{\mathrm{NS}}$ & $0.094^{\mathrm{NS}}$ & $0.104^{\mathrm{NS}}$ & $0.009^{\mathrm{NS}}$ & $0.159^{\mathrm{NS}}$ & 1.00 & & & & \\
\hline \multirow[t]{3}{*}{$\% \mathrm{BS}$} & UP & $0.11^{\mathrm{NS}}$ & $0.087^{\mathrm{NS}}$ & $0.09^{\mathrm{NS}}$ & $0.198^{\mathrm{NS}}$ & $0.00^{\mathrm{NS}}$ & $0.63^{\mathrm{NS}}$ & 1.00 & & & \\
\hline & PwoV & $0.18^{\mathrm{NS}}$ & $0.42^{\mathrm{NS}}$ & $0.417^{\mathrm{NS}}$ & $0.14^{\mathrm{NS}}$ & $0.00^{\mathrm{NS}}$ & 0.833 & 1.00 & & & \\
\hline & $\mathrm{PwV}$ & $0.116^{\mathrm{NS}}$ & $0.25^{\mathrm{NS}}$ & $0.234^{\mathrm{NS}}$ & $0.008^{\mathrm{NS}}$ & $0.171^{\mathrm{NS}}$ & $0.52^{\mathrm{NS}}$ & 1.00 & & & \\
\hline \multirow[t]{3}{*}{ TN } & UP & $0.09^{\mathrm{NS}}$ & $0.49^{\mathrm{NS}}$ & $0.49^{\mathrm{NS}}$ & $0.15^{\mathrm{NS}}$ & $0.003^{\mathrm{NS}}$ & $0.00^{\mathrm{NS}}$ & $0.165^{\mathrm{NS}}$ & 1.00 & & \\
\hline & PwoV & $0.21^{\mathrm{NS}}$ & $0.09^{\mathrm{NS}}$ & $0.088^{\mathrm{NS}}$ & $0.144^{\mathrm{NS}}$ & $0.25^{\mathrm{NS}}$ & $0.72^{*}$ & $0.42^{\mathrm{NS}}$ & 1.00 & & \\
\hline & $\mathrm{PwV}$ & $0.21^{\mathrm{NS}}$ & $0.46^{\mathrm{NS}}$ & $0.45^{\mathrm{NS}}$ & $0.073^{\mathrm{NS}}$ & $0.29^{\mathrm{NS}}$ & $0.22^{\mathrm{NS}}$ & 0.82 & 1.00 & & \\
\hline \multirow[t]{2}{*}{$\mathrm{OM}$} & $\begin{array}{l}\text { UP } \\
\text { PwoV }\end{array}$ & $\begin{array}{l}0.09^{\mathrm{NS}} \\
0.14^{\mathrm{NS}}\end{array}$ & $\begin{array}{l}0.0646^{\mathrm{NS}} \\
0.55^{\mathrm{NS}}\end{array}$ & $\begin{array}{l}0.65^{\mathrm{NS}} \\
0.55^{\mathrm{NS}}\end{array}$ & $\begin{array}{l}0.047^{\mathrm{NS}} \\
0.065^{\mathrm{NS}}\end{array}$ & $\begin{array}{l}0.00^{\mathrm{NS}} \\
0.055^{\mathrm{NS}}\end{array}$ & $\begin{array}{l}0.276^{\mathrm{NS}} \\
0.097^{\mathrm{NS}}\end{array}$ & $\begin{array}{l}0.49^{\mathrm{NS}} \\
0.83\end{array}$ & $\begin{array}{l}0.042^{\mathrm{NS}} \\
0.68\end{array}$ & $\begin{array}{l}1.00 \\
1.00\end{array}$ & \\
\hline & $\mathrm{PwV}$ & $0.003^{\mathrm{NS}}$ & $0.017^{\mathrm{NS}}$ & $0.015^{\mathrm{NS}}$ & $0.071^{\mathrm{NS}}$ & $0.007^{\mathrm{NS}}$ & $0.005^{\mathrm{NS}}$ & $0.278^{\mathrm{NS}}$ & $0.51^{\mathrm{NS}}$ & 1.00 & \\
\hline \multirow[t]{3}{*}{ Av.P } & $\begin{array}{l}\text { UP } \\
\text { PwoV }\end{array}$ & $\begin{array}{l}0.01^{\mathrm{NS}} \\
0.76\end{array}$ & $\begin{array}{l}0.005^{\mathrm{NS}} \\
0.11^{\mathrm{NS}}\end{array}$ & $\begin{array}{l}0.004^{\mathrm{NS}} \\
0.11^{\mathrm{NS}}\end{array}$ & $\begin{array}{l}0.017^{\mathrm{NS}} \\
0.631^{\mathrm{NS}}\end{array}$ & $\begin{array}{l}0.00^{\mathrm{NS}} \\
0.356^{\mathrm{NS}}\end{array}$ & $\begin{array}{l}0.011^{\mathrm{NS}} \\
0.288^{\mathrm{NS}}\end{array}$ & $\begin{array}{l}0.023^{\mathrm{NS}} \\
0.397^{\mathrm{NS}}\end{array}$ & $\begin{array}{l}0.034^{\mathrm{NS}} \\
0.144^{\mathrm{NS}}\end{array}$ & $\begin{array}{l}0.004^{\mathrm{NS}} \\
0.33^{\mathrm{NS}}\end{array}$ & $\begin{array}{l}1.00 \\
1.00\end{array}$ \\
\hline & $\mathrm{PwV}$ & $0.09^{\mathrm{NS}}$ & $0.378^{\mathrm{NS}}$ & $0.36^{\mathrm{NS}}$ & $0.031^{\mathrm{NS}}$ & $0.176^{\mathrm{NS}}$ & $0.282^{\mathrm{NS}}$ & 0.79 & 0.96 & $0.58^{\mathrm{NS}}$ & 1.00 \\
\hline & & Clay & $\mathrm{Pb}$ & F & SCR & $\mathrm{pH}$ & ECEC & $\%$ BS & $\mathrm{TN}$ & $\mathrm{OM}$ & Av.P \\
\hline
\end{tabular}

$\widehat{\ell \mathrm{b}}=$ Bulk density; F=Porosity; SCR=Silt:clay ratio; ECEC=effective cation exchange capacity; \%BS=Percent base saturation; TN=Total nitrogen; OM=Organic matter; Av.P=Available phosphorus: $\mathrm{CNR}=\mathrm{Carbon}$ :nitrogen ratio; $\mathrm{CMR}=\mathrm{Calcium}$ :magnessium ratio; UP=Unpolluted soil; PwoV=Polluted without vegetation; $\mathrm{PwV}=$ Polluted with vegetation; NS: Not significant 
Int. J. Environ. Sci. Tech., 7 (2), 261-270, Spring 2010

Table 4: Variability in some physicochemical properties of studied soils $(\mathrm{N}=15)$

\begin{tabular}{|c|c|c|c|c|c|c|c|c|c|c|c|c|}
\hline Sample & Clay & $\ell \mathrm{b}$ & $\mathrm{F}$ & SCR & $\mathrm{pH}_{\text {water }}$ & ECEC & \%BS & $\mathrm{TN}$ & $\mathrm{OM}$ & Av.P & $\mathrm{C}: \mathrm{N}$ & C:M \\
\hline Unit & $(\mathrm{g} / \mathrm{kg})$ & $(\mathrm{g} / \mathrm{cm})$ & (\%) & & & $(\mathrm{mg} / \mathrm{kg})$ & & & (mg/kg) & & & Ratio \\
\hline UP & 21 & 1.25 & 47.17 & 4.0 & 6.48 & 9.5 & 94.84 & 1.3 & 189.5 & 6.15 & 8.6 & 4.52 \\
\hline PwoV & 30 & 1.36 & 51.32 & 3.9 & 6.84 & 25.41 & 98.50 & 1.7 & 320.6 & 3.20 & 11.0 & 0.18 \\
\hline PwV & 22 & 1.33 & 50.1 & 2.34 & 6.75 & 14.32 & 96.84 & 1.5 & 272.4 & 1.25 & 10.8 & 0.25 \\
\hline $\operatorname{LSD}_{0.05}$ & 6.16 & 0.035 & 1.28 & 0.94 & 0.09 & 0.76 & 0.47 & 0.25 & 22.9 & 0.26 & $2.21^{\mathrm{NS}}$ & 0.57 \\
\hline
\end{tabular}

$\ell \mathrm{b}=$ =Bulk density; F=Porosity; SCR=Silt:clay ratio; ECEC=effective cation exchange capacity; \%BS=Percent base saturation; TN=Total nitrogen; OM=Organic matter; Av.P=Available phosphorus: C:NR=Carbon:nitrogen ratio; C:MR=Calcium:magnessium ratio; UP=Unpolluted soil; PwoV=Polluted without vegetation; PwV=Polluted with vegetation; NS: Not significant

resulting in clay lessivage could have led to the sandiness of the soils (Unamba-Oparah et al., 1987; Eshett et al., 1990). This characteristic may led to the low bulk density of the soils and therefore high porosity (Landon, 1991). Soils with such high porosity provide avenue for eutrophication of groundwater leading to it's pollution. Also, at increased bulk density as was the case for crude-oil-polluted soils, there was reduced porosity and this attenuated porosity results in reduced aeration and oxygen availability. Thus, the activities of aerobes would therefore be affected leading to poor microbial functions in the pedosphere. Schwendinger (1968) noted that crude-oil contamination of soils leads to the formation of an anaerobic condition in the soil. Rowell (1977) reported that insufficient aeration results in the soil because of displacement of air from the spaces between soil particles by crude oil and thus makes it unsatisfactory for plant growth. Moisture content of polluted soils were higher than that of unpolluted soils. This could have resulted from the anaerobic conditions of polluted soils. Fresh crude oil shows a coagulatory effect on the soil, binding the soil particles into a water impermeable soil block, which seriously impairs water drainage and oxygen diffusion, and seeds sown in such soil failed to germinate (Atuanya, 1987).

\section{Chemical properties}

Soil reaction otherwise expressed as soil $\mathrm{pH}$ determines the fate of many soil pollutants (Brady and Weil, 1999). Ogaji et al. (2005) reported increase in soil $\mathrm{pH}$ with crude-oil pollution. This was similar to this study. The increased soil $\mathrm{pH}$ of crude oil polluted soils affected the soils' effective cation exchange capacity, as effective cation exchange capacity increased with increased pH (Singer and Munns, 1999). Available P has been noted to be limiting in crude oil polluted soils (Ladousse and Tramier, 1991; Amadi and Bari, 1992;
Table 5: Variability of $\mathrm{Zn}$ in studied soils

\begin{tabular}{ll}
\hline & Zn $(\mathrm{mg} / \mathrm{kg})$ \\
\hline UP & 98.8 \\
PwoV & 156.8 \\
PwV & 211.9 \\
LSD $_{0.05}$ & 27.09 \\
\hline
\end{tabular}

Amadi et al., 1993). Higher values of organic matter in crude oil polluted soils have resulted from the increased hydrocarbon content (which caused high organic carbon content of polluted soils) of oil polluted soils and organic matter is a product of organic carbon.

Similar finding has been reported by Ogaji et al. (2005). Total N equally increased with crude oil pollution, implying higher total $\mathrm{N}$ values in polluted without vegetation and polluted with vegetation, respectively. It was noted in this study that organic matter positively correlated with total N. UnambaOparah (1982) found a positive correlationship between organic matter and total $\mathrm{N}$ in soils. Therefore, the increased values of total $\mathrm{N}$ in oil polluted soils would have been contributed by organic matter. Carbon:nitrogen ratio was observed to have been widened by the presence of crude-oil in soils (Amadi and Bari, 1992). This was corroborated in this study. Landon (1991) reported that a decrease of Ca:Mg ratio to a level below 3 leads to the unavailability of $\mathrm{Ca}^{2+}$ and P. Calcium:magnessium ratio reduced with oil pollution and this equally affected $\mathrm{Ca}^{2+}$ and $\mathrm{P}$ availability in polluted soils (Table 2).

\section{Zinc availability in relation to selected soil properties in studied soils \\ Total $\mathrm{Zn}$ content of soils is largely dependent on the composition of the parent rock materials (Kabata- Pendias and Pendias, 1992) other factors such as $\mathrm{pH}$, organic matter content, temperature, high P levels, clay and other soil nutrients (Alloway, 1995) affect Zn availability in soils.}


M. C. Chukwuma et al.
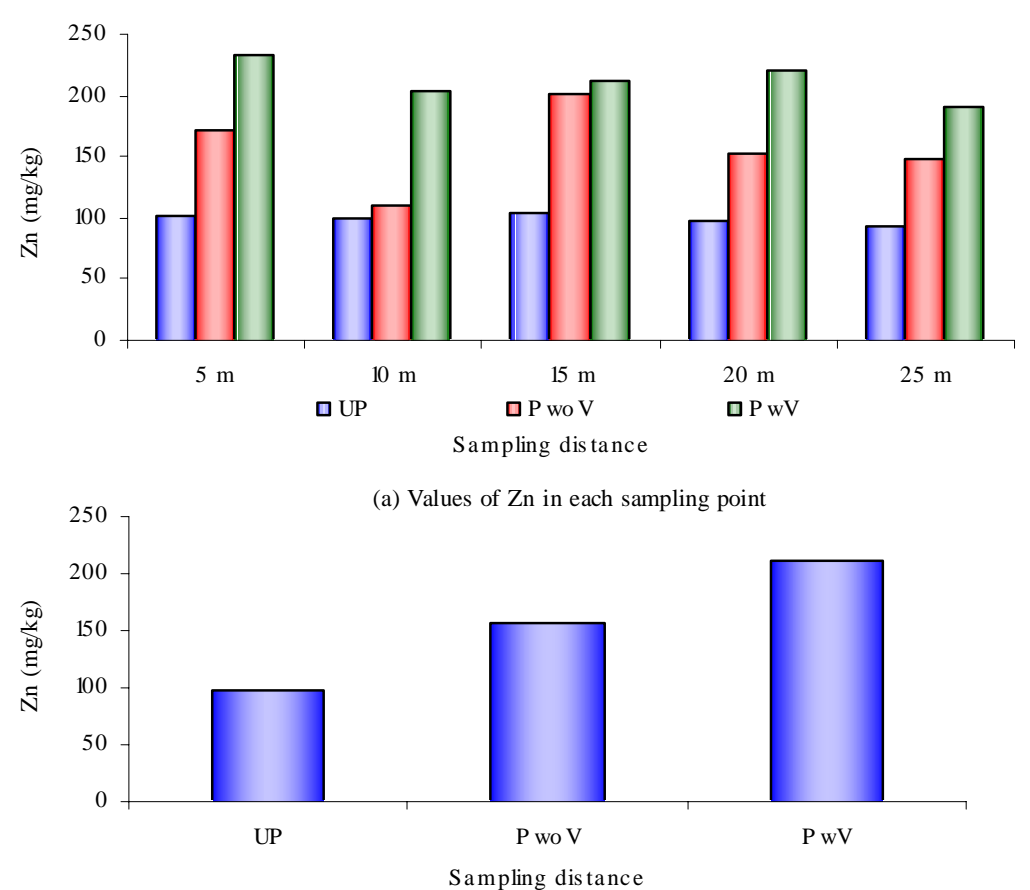

(b) Mean values of $\mathrm{Zn}$ in studied soils

Fig. 1: Concentrations of $\mathrm{Zn}$ in studied soils
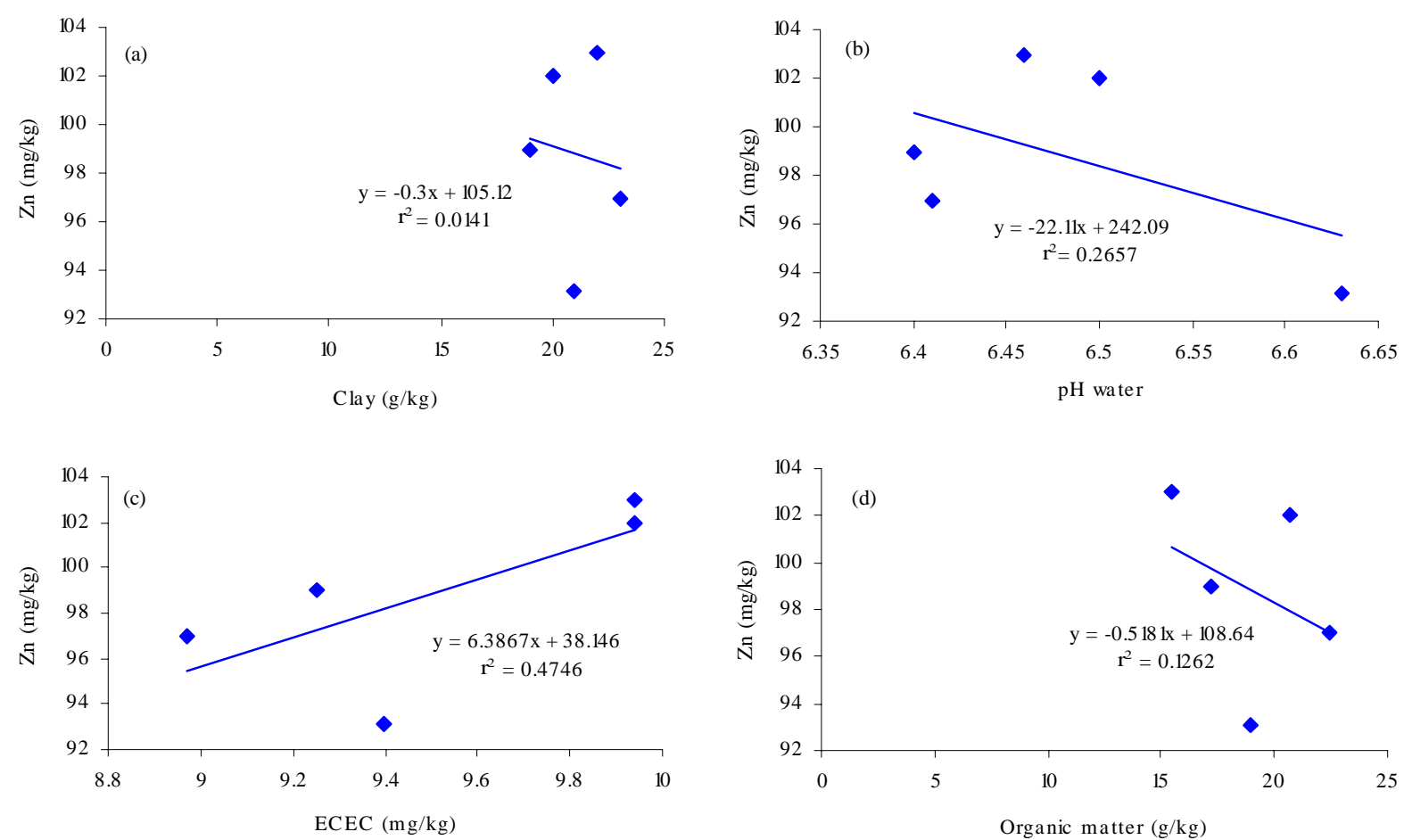

Fig. 2: The relationship between $\mathrm{Zn}$ and clay, $\mathrm{pH}$, ECEC and organic matter, respectively in unpolluted soil (UP) 

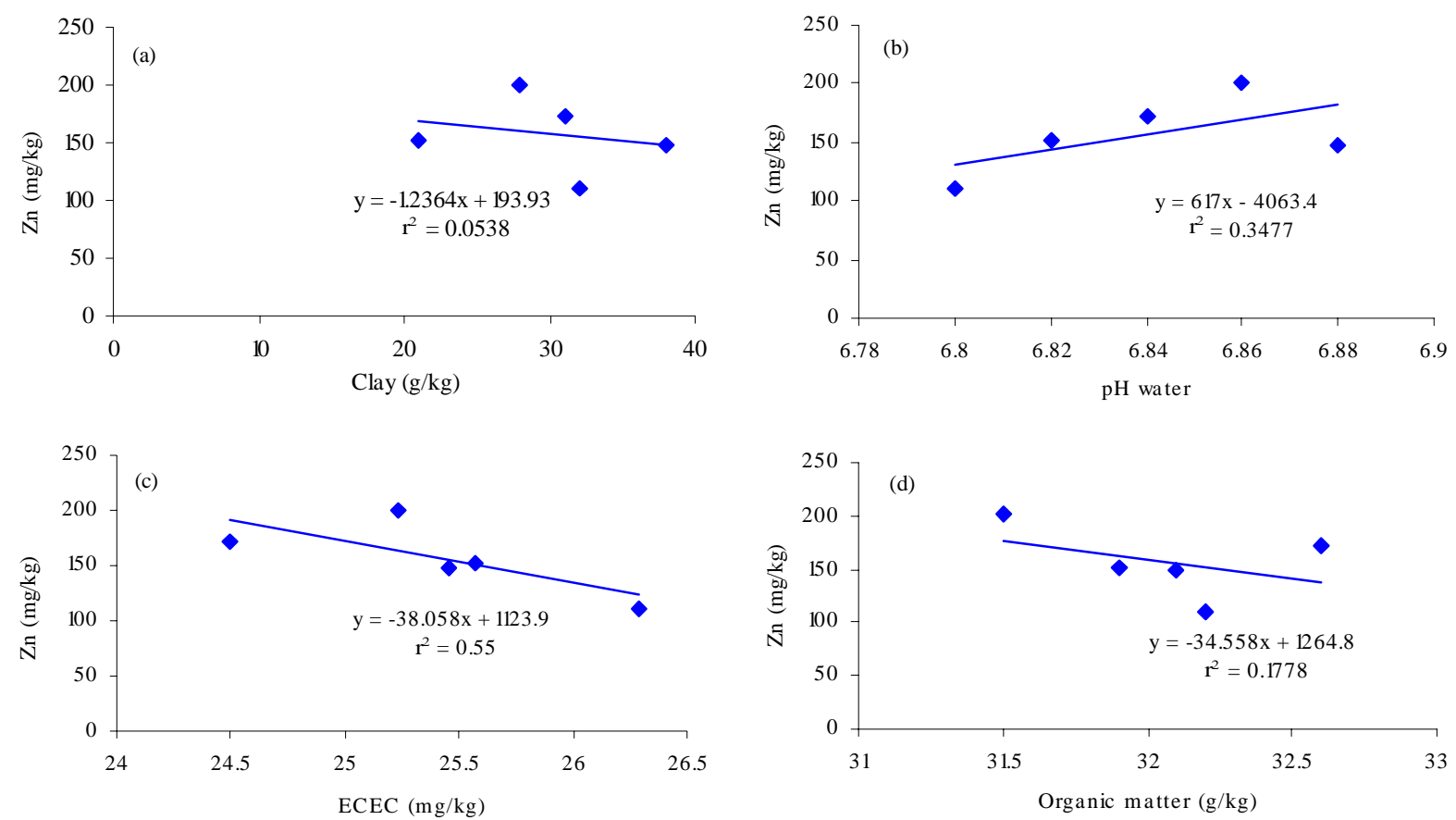

Fig. 3: The relationship between $\mathrm{Zn}$ and Clay, $\mathrm{pH}, \mathrm{ECEC}$ and organic matter respectively in polluted soil without vegetation (PwoV)
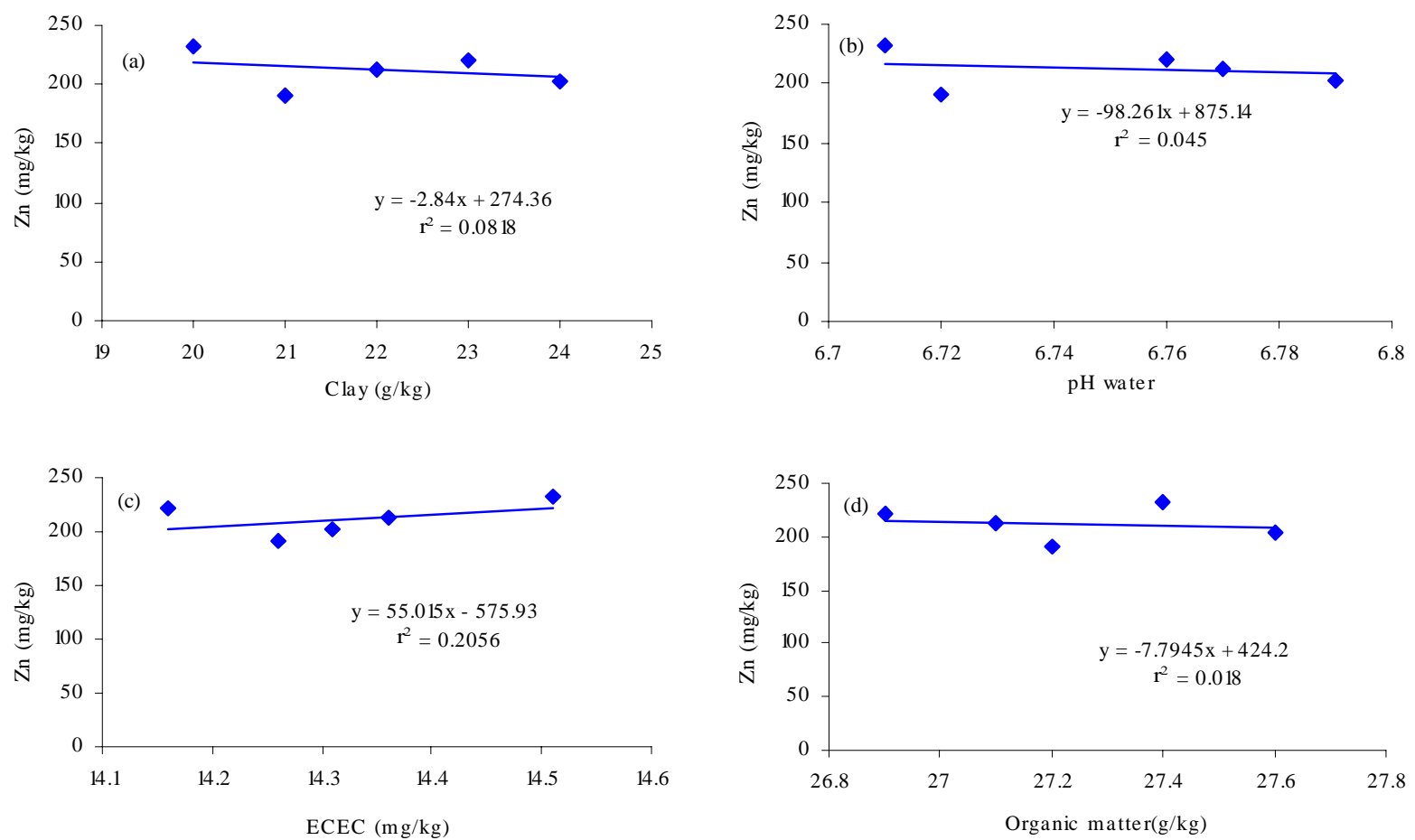

Fig. 4: The relationship between $\mathrm{Zn}$ and clay, $\mathrm{pH}$, ECEC and organic matter respectively in polluted soil with vegetation 
In this study, clay fraction of the soil texture that was not polluted with crude-oil showed negative correlation with Zn (Fig. 2a). Similarly, clay equally correlated with $\mathrm{Zn}$ in crude-oil-polluted this time with higher $\mathrm{r}^{2}$ values (Figs. 3a and $4 \mathrm{a}$ ). Though there was clay increases in oil-polluted soils, it was however observed that at increasing clay content, $\mathrm{Zn}$ was decreasing. Higher values of $\mathrm{Zn}$ were obtained in crude-oil-polluted soils. Given the equations in Figs. 2a, 3a and 4a, respectively, if clay is put at zero (0), Zn would be highest in polluted with vegetation (274.3 $\mathrm{mg} / \mathrm{kg}$ ), followed by polluted without vegetation (193.9 $\mathrm{mg} / \mathrm{kg}$ ) and least in unpolluted (105.1 mg/kg). This portents that $\mathrm{Zn}$ availability in relation to clay was affected by crude oil pollution. This observed correlationship between $\mathrm{Zn}$ and clay was corroborated by Kiekens (1986) which he reported was due to Zn adsorption by clayey fraction of the soil.

In the three studied soils (unpolluted, polluted without vegetation and polluted with vegetation), organic matter negatively correlated with Zn (Figs. 2d, 3d and 4d). This implied that at increasing organic matter, Zn was decreasing. Organic matter have been reported to form stable complexes with micronutrients such as Zn (Alloway, 1995). This complexation or chelation leads to its unavailability. Onweremadu (2008) reported that organic matter promoted fixation of heavy metals in soils contaminated with waste water in Owerri, Nigeria. Therefore, Zn availability was not affected in crude oil polluted soils in relation organic matter. The availability of $\mathrm{Zn}$ decreases at increasing $\mathrm{pH}$ values of the soil, due to the lower solubility of $\mathrm{Zn}$ minerals and increasing adsorption of $\mathrm{Zn}$ by negatively charged colloidal soil particles (Alloway, 1995). Zinc availability in unpolluted and polluted with vegetation increased with decreasing soil $\mathrm{pH}$ (Figs. $2 \mathrm{~b}$ and $4 \mathrm{~b}$ ), however, in polluted without vegetation the relationship was different (Fig. 3b) as there was positive correlationship. The effect of crude oil pollution on $\mathrm{Zn}$ availability in relation to $\mathrm{pH}$ could not be effectively ascertained because of the conflicting results in polluted without vegetation and polluted with vegetation. This not withstanding, the presence of vegetation could have accounted for this variation. In unpolluted soils, Zn showed a positive correlation with effective cation exchange capacity. This implied that $\mathrm{Zn}$ tended to be more available at increasing soil effective cation exchange capacity (Fig. 2c). This was same for crudeoil-polluted soil with vegetation (Fig. 3c). It however had a negative correlation with effective cation exchange capacity in polluted soil without vegetation. At neutral or normal soil $\mathrm{pH}$ values $\mathrm{Zn}$ is adsorbed reversibly by ion-exchange and irreversibly by lattice penetration of clay minerals (Tiller and Hodgson, 1962). It is evident that soil $\mathrm{pH}$ in polluted without vegetation presented better sorptive sites for Zn adsorption thus reducing its availability at increasing effective cation exchange capacity.

Alloway (1995) concluded that clay minerals, organic matter and $\mathrm{pH}$ are likely to be the most important factors affecting $\mathrm{Zn}$ adsorption by soils. This is consistent with the findings of this study, where only effective cation exchange capacity positively correlated with Zn in unpolluted soil. Shuman (1975) studied the effect of soil properties on Zn availability and found that soils high in clay or organic matter had higher adsorption capacity for $\mathrm{Zn}$ than sandy soils low in organic matter.

\section{CONCLUSION}

It was found that crude oil pollution affected some soil properties. Zinc availability was affected by some soil properties in the crude oil polluted Eutric Tropofluvent. $\mathrm{pH}$ and effective cation exchange capacity affected $\mathrm{Zn}$ availability with crude-oil pollution. With increase in $\mathrm{pH}$, $\mathrm{Zn}$ decreased in unpolluted and polluted with vegetation, but increased in polluted without vegetation. While on effective cation exchange capacity, $\mathrm{Zn}$ increased with increase in the value of effective cation exchange capacity in unpolluted and polluted without vegetation, but decreased in polluted with vegetation. However, clay and organic matter did not affect Zn availability with crude-oil pollution as Zn decreased with increased clay and organic matter content, respectively. This therefore necessitates the need for further study on Zn dynamics in crude oil polluted soils since it is an essential micronutrient for plant growth. Also, there is the need for quick reclamation of the soils in order to save fragile arable soils from degradation.

\section{REFERENCES}

Alloway, B. J., (1995). Heavy metals in soils. $2^{\text {nd. Ed. Chapman }}$ and Hall, Glasgow, 34.

Alvarez-Benedi, J.; Munoz-Carpena, R., (2005). Soil, water, solute process characterization. An integrated approach. C.R.C Press, Florida. 538.

Amadi, A; Dickson, A. A.; Maate, G. O., (1993). Remediation of oil polluted soils: Effect of organic and inorganic nutrient supplements on the performance of Maize. J. Water Air, Soil Pollut. 66 (1-2), 59-76 (8 pages). 
Amadi, A.; Bari, Y. U., (1992). Use of poultry manure for the amendment of oil polluted soils in relation to growth of maize. Environ. Int., 18, 521-527 (7 pages).

Atuanya, E. J., (1987). Effect of oil pollution on physical and chemical properties of soil: A case study of waste oil contaminated delta soil in Bendel State, Nigeria. J. Appl. Sci., 55, 155-176 (22 pages).

Bellamy, P., (2007). Dictionary of environment. Academic Publishers, New Delhi, India.

Brady, N. C.; Weil, R. R., (1999). The nature and properties of soil. $12^{\text {th. }}$ Ed. Prentice-Hall, Inc. New Jersey 07458.

Bremner, J. M., (1996). Nitrogen total. Sparks, D. L., (Ed.). Methods of soils analysis, part 3, chemical method. $2^{\text {nd. }}$ Ed, SSSA Book Series No. 5, SSSA, Madison, W.I., 1085-1121.

Buysse, W.; Stern, R.; Coe, R.; McDermott, B.; Muchiri, S.; Okello, M.; Kurji, P.; Obudho, E.; Mong'are, P., (2005). GenStat $8^{\text {th. }}$ Ed. for everyday use. ICRAF Nairobi, Kenya. 114.

Eshett, E. T.; Omueti, A. I.; Juo, A. S. R., (1990). Physicochemical, morphology and clay mineralogical properties of soils overlying basement complex rocks in Ogoja, northern cross river State of Nigeria. Soil Sci. Plant Nutr., 36 (2), 203-214 (12 pages).

FDALR, (1985). The reconnaissance soil survey of Imo state, Nigeria, Federal Department of Agricultural Land Resources $(1: 250,000)$, Soil report, 133

Gee, G. W.; Or, D., (2002). Particle size distribution. in: Dane, J. H.; Topp, G. C. (Eds). Methods of soil analysis, part 4. Physical methods. Soil Sci. Soc. Am Book Series No.5, ASA and SSSA, malison, WI., 255-293.

Grossman, R. B.; Reinsch, T. G., (2002). Bulk density and linear extensibility. in: Dane, J. H.; Topp, G. C. (Eds.). Methods of the soil analysis part 4. Physical methods. Soil Sci. Soc. Am. Book Series No.5, ASA and SSSA, Madison, WI., 201-228.

Hendershort, W. H., Lalande, H.; Duquette, M., (1993). Soil reaction and exchangeable acidity. in: Carter M. R. (Ed.). Soil Sampling and methods of soil analysis, Canadian Soc. Soil Sci., Lewis Publishers, London, 141-145 (5 pages).

Isirimah, N. O.; Zuofa, K.; Loganathan, P., (1989). Effect of crude oil on maize performance and soil chemical properties in humid forest zone of nigeria. Discov. Innovat., 1 (3), 2334 (12 pages).

Jungerius, P. D.; Levellt, T. W., (1964). Clay mineralogy of soils over sedimentary rocks in Eastern Nigeria. Soil Sci., 97 (2), 89-95 (7 pages).

Kabata-Pendias, A.; Pendias, H., (1992). Trace elements in soils and plants. $2^{\text {nd. }}$ Ed., CRC Press, Boca Raton, Fla.

Kiekens, L., (1986). Calculated Langmuir parameters for Zn adsorption by soils. Academiae Analecta.

Ladousse, A.; Tramier, B., (1991). Results of 12 years of research in spilled oil bioremediation, Inipol EAP22, Proceeding 1991 Oil Spill Conference, American petroleum Institute, Washington, DC.

Landon, J. R., (1991). Booker tropical manual: A handbook for soil surveyand agricultural land evaluation in the tropic and subtropics: Longman Inc., New York.

Leschber, R.; Davis, R. D.; L’Hermite, P., (1985). Chemical methods for assessing bioavailable metals in sludges and soils. Elsevier, Amsterdam.

Lorenz, S. E.; Hamon, R. E.; Holm, P. E.; Domingues, H. C.; Sequeiria, E. M.; Christensen, T. H.; McGrath, S. P., (2000).
Cadmium and zinc speciation in heavy metal contaminated soils from six European countries. Bioresour. Tech. 71 (3), 254-259 (6 pages).

Mclean, E. V., (1982). Aluminum,. in: Page, A. L., Miller, R. H.; Keeney, D. R. (Eds.). Methods of soil analysis, part 2, Am. Soc. Agron. Madison, WI. 978-998.

Nabulo, G.; Oryem Origa, H.; Nasinyama, G. W.; Cole, D., (2008). Assessment of $\mathrm{Zn}, \mathrm{Cu}, \mathrm{Pb}$ and $\mathrm{Ni}$ contamination in wetland soils and plants in the lake basin. Int. J. Environ. Sci. Tech., 5 (1), 65-74 (10 pages)

Nelson, D. W.; Sommers, L. E., (1982). Total carbon, organic carbon and organic matter. in: Page, A. L.; Miller, R. H.; Keeney, D. R. (Eds.). Methods of soil analysis, part 2, Am. Soc. Agron., Madison WI, 539-579.

NMHPPE, (1991). Environmental quality standards for soil and water. Netherlands Ministry of Housing, Physical Planning and Environment. Leidschendam, Netherlands.

Nwilo, P. C.; Badejo, O. T., (2001). Impacts of oil spills along the Nigeria Coast. www.aehsmag.com/issues/2001/october/ impacts.html.

Obi, M. E., (1990). Soil physics. A compendium of lectures. Department of Soil Science, U.N.N. 103.

Ogaji, S. O. T; Ayotamuno, M. J; Kogbara, R. B.; Probert, S. D., (2005). Bioremediation of a crude oil polluted agricultural soil at Port-Harcourt, Nigeria. School of Engineeeering, Cranfield University, Bedfordshire, UK.

Ogundiran, O. O.; Afolabi, T. A., (2008). Assessment of the physicochemical parameters and heavy metals toxicity of leachates from municipal solid waste open dumpsite. Int. J. Environ. Sci. Tech., 5 (2), 243-250 (8 pages)

Okafor, E. C.; Opuene, K., (2007). Preliminary assessment of trace metals and polycyclic aromatic hydrocarbons in the sediments. Int. J. Environ. Sci. Tech., 4 (2), 233-240 (8 pages)

Okpokwasili, G. C.; Odokuma, L. O., (1990). Effect of salinity on biodegradation of oil spills dispersants. Waste Manage. 10 (2), 141-146 (6 pages).

Olson, S. R.; Sommers, L. E., (1990). Phosphorus. in: Page, A. L. (Ed.). Methods of Soil Analysis. Parts 2, Agron., Monogr. No. 9 Madison, WI. 403-431.

Onweremadu, E. U., (2007). Pedology of near gully sites and its implications on the erodibility of soils in central SouthEastern Nigeria. Res. J. Environ. Sci., 1 (2), 71-76 (6 pages).

Onweremadu, E. U., (2008). Physico-chemical charaterisation of a farmland affected by wastewater in relation to heavy metals. J. Zhejiang U. Sci. A., 9 (3), 366-372 (7 pages).

Onweremadu, E. U.; Duruigbo, C. I., (2007). Assessment of cadmium concentration of crude oil polluted arable soils. Int. J. Environ. Sci. Tech., 4 (3), 409-412 (4 pages).

Orajaka, S. O., (1975). Geology. In: Nigeria in maps: Eastern States. in: Ofomata, G. E. K. (Ed.). Ethiope Publishers. Benin city Nigeria, 5-7 (3 pages).

Rowell, M. J., (1977). The Effect of crude oil spills on soils: A review of literature. in: Toogood, J. A. (Ed.), The reclamation of agricultural soils after oil spills, part 1, Edmonton, Canada. $1-33$.

Schwendinger, R. B., (1968). Reclamation of soil contaminated with oil. J. Inst. Petrol., 54, 535-543 (9 pages).

Shuman, L. M., (1975). The effect of soil properties on zinc adsorption by soils. Soil Sci. Soc. Am. J., 39, 454-458 (5 pages). 


\section{C. Chukwuma et al.}

Singer, M. J.; Munns, D. N., (1999). Soils, an introduction. $4^{\text {th. }}$ Ed. Prentice-Hall, Inc. New Jersey.

Smolders, E.; Buekers, J.; Oliver, I.; McLaughlin, M. J., (2004). Soil properties affecting toxicity of zinc to soil microbial properties in laboratory-spiked and field-contaminated soils. Environ. Toxic. Chem., 23 (11), 2633-2640 (8 pages)

Suthar, S.; Singh, S., (2008). Vermicomposting of domestic waste by using two epigeic earthworms (Perionyx excavatus and Perionyx sansibaricus). Int. J. Environ. Sci. Tech., 5 (1), 99-106 (8 pages).

Tiller, K. G.; Hodgson, J. F., (1962). The specific sorption of cobalt and zinc by layer silicates. Clay. Clay Miner., 9, 393403 (11 pages).
Udo, E. J.; Fayemi, A. A. A., (1975). The effect of oil pollution of soil on germination, growth and nutrient uptake of corn. J. Environ. Qual., 4, 537-540 (4 pages).

Unamba-Oparah, I., (1982). Comparison of the carbon and nitrogen contents and their relationships to other soil properties in some important soils of Southeastern Nigeria. Beitrage trop. Landwirtsch. Veterinarmed, 20, H.2, 167176 (10 pages)

Unamba-Oparah, I.; Wilson, M. J.; Smith, B. F. L., (1987). Exchangeable cations and mineralogy of some selected Nigerian soils. Appl. Clay Sci., 2, 105-128 (24 pages).

Unger, P. W.; Kaspar, T. C., (1994). Soil compaction and root growth. Rev. Agron. J., 86, 759-766 (8 pages).

\section{AUTHOR (S) BIOSKETCHES}

Chukwuma, M. C., M.Sc. student, Department of Soil Science and Technology, Federal University of Technology, Owerri, Imo State, Nigeria. Email:chukwumamike@yahoo.co.uk

Eshett, E. T., Full Professor, Department of Soil Science and Technology, Federal University of Technology, Owerri, Imo State, Nigeria. Email: etteeshet@yahoo.com

Onweremadu, E. U., Ph.D., Lecturer, Department of Soil Science and Technology, Federal University of Technology, Owerri, Imo State, Nigeria. Email: uzomaonweremadu@yahoo.com

Okon, M. A., Graduate Assistant, Department of Soil science, Federal University of Technology, P.M.B. 1526, Owerri, Nigeria. Email: mikedchosen@yahoo.com

How to cite this article: (Harvard style)

Chukwuma, M. C.; Eshett, E. T.; Onweremadu, E. U.; Okon, M. A., (2010). Zinc availability in relation to selected soil properties in a crude oil polluted eutric tropofluvent. Int. J. Environ. Sci. Tech., 7 (2), 261-270. 